\title{
An Evaluation of Academic Training Program (ÖYP) from Professional Socialisation and Identity Perspective
}

\author{
Tijen Tülübaş $^{1^{*}} \quad$ Şöheyda Göktürk ${ }^{2}$ \\ 1.School of Foreign Languages, Namık Kemal University, Tekirdağ, Turkey \\ 2.Faculty of Education, Kocaeli University, Kocaeli, Turkey
}

\begin{abstract}
Academic identity is significant in terms of taking the responsibilities of professional roles and performing them adequately. Identity formation starts from the early socialisation experiences of graduate students and develops on what they have acquired during this process. Therefore, Academic Training Program is significant for determining the academic identity of future academics. A review of the literature reveals a lack of research that evaluates Academic Training Program (ÖYP), especially from existing faculty's point of view, with an identity development perspective. This study aims to investigate the Academic Training Program (ÖYP) in the light of academics' definition of the characteristics of academic profession, with a focus on professional socialisation and identity development. This qualitative, collective instrumental case study was conducted with 24 academics selected through the maximum variation sampling method from two typical Turkish universities. The content analysis of data revealed that the Academic Training Program (ÖYP) has some adverse effects on the professional development of recruits since the program is not fully compatible with the requirements of academic profession.
\end{abstract}

Keywords: Academic Training Program (ÖYP), academic identity, graduate education, professional socialisation

\section{Introduction}

Higher education institutions are significant in the development of today's knowledge societies, and the success of a higher education institution mainly lies in the genuine efforts of academics as they are primarily responsible from the accomplishment of its core tasks. Therefore, understanding academics' beliefs and ideas regarding the essentials of their profession is significant since these beliefs and ideas shape their professional attitudes, behaviours, judgments and values, that's, their professional identity (Arasa \& Calvert, 2013; Austin, 1990). Similarly, as defined by Bruss and Kopala (1993), identity is directly connected to one's taking the responsibilities of professional roles and adhering to professional ethics.

Professional identity refers to the experiences, motives, beliefs and values that characterize individuals practicing the same profession (Ibarra, 1999), and defines the choice of "what the individual will stand for and be recognized as" (Josselson, 1987, p. 8) being a member of that particular profession. Professional identity is a complex, personal entity that is mainly shaped through interpretation and reinterpretation of professional experiences (Beijaard, Meijer, \& Verloop, 2004). Therefore, professional identity development happens as part of one's socialization into the profession not only in terms of acquisition of professional skills and knowledge but also in terms of developing commitments to and identification with the essences of the profession (Reybold, 2003).

The key concepts of academic identity required to make an academic a successful professional can only be transformed through professional education and experience (Henkel, 2000; Kogan, 2000). Therefore, the period of graduate education, particularly $\mathrm{PhD}$ education, marks the beginning of academics' professional socialization and development of academic identity. Weidman, Twale and Stein (2001) define socialization in graduate school as "the processes through which individuals gain the knowledge, skills and values necessary for successful entry into a professional career" (p. 5). From this point of view, socialization is not only a conscious process of gaining subject mastery and knowledge application but also a subconscious process of internalizing behavioural norms and standards and forming a sense of identity and commitment to the profession. Tierney and Rhoads (1993) also highlight the importance of graduate education in academics' professional socialization and becoming a solid member of the academic community. Hence, higher education policies regulating the entry into academe and academic profession like Academic Training Program (ÖYP) are significant due to determining socialization processes that will shape the candidates' academic identity.

\section{Academic Training Program (ÖYP)}

Academic Training Program has been designed for the recruitment and training of future academics and the idea behind the establishment of the program is to enhance the faculty capacity of newly established universities through collaboration with developed universities. The program was first initiated in 2001 with the leadership of Middle East Technical University (METU) and funded by Prime Ministry State Planning Organization (Now, the name of the organization is Ministry of Development). Students for the program were then jointly selected by 
METU and the other collaborating universities. With the new higher education policy promising "one university in every city", approximately 50 new universities have been established. As a result, the need for qualified academics has considerably increased. Despite the rising number of universities, many of them could not offer graduate programs to train future faculty. Hence, ÖYP has been considered to be an effective means of meeting this demand for qualified academics. Thus, the program has become nation-wide under the control of the Council of Higher Education (CHE) since 2010, and students are assigned centrally by CHE.

Within this program (ÖYP), the university having the capacity to conduct $\mathrm{PhD}$ programs (the host university) collaborates with partner universities which are newly established, developing universities. Students selected for the program are first recruited to these partner universities, and then sent to the host university to do their graduate studies. Upon completing their education, recruits return to their universities to work as faculty members. Students are economically and legally supported to receive maximum 3 months short-term overseas or domestic visits to receive language training, and a maximum one-year-long visit as part of their doctoral research. They can also receive annual project support to be used for research equipments, expandable supplies and travel expenses.

To be eligible for the program, applicants are required to be under the age of 35 and possess a minimum score of 70 from ALES (Academic Personnel and Post-graduate Training Examination). Applicants' ÖYP scores are calculated with the $35 \%$ of bachelor's grade point average, $50 \%$ ALES score, and $15 \%$ of language proficiency exam score (optional), and they are selected based on this ÖYP score. Students selected for the program sign a contract and a bill, which confirms that research assistants will work in their affiliated universities for a period as long as their graduate education or else they will reimburse the total amount of salaries they received during their education. In other words, students are obliged for a compulsory service following their graduate education.

\subsection{Studies Evaluating ÖYP}

Since the establishment of the program, several studies have been conducted with research assistants joining the program. The findings of the studies show that

- $\quad$ although many of the participants preferred the program to start an academic career, job guarantee was a significant reason for their preference (Erdoğan, 2013).

- the program has not been run as defined in legislation, which results in uncertainty of employment procedures, insufficient financial support and problems with the definition of job roles (Çelebi \& Tatık, 2012; Memiş \& Sağır, 2013).

- $\quad$ participants are unwilling to return to their protocol universities, and they feel the strong pressure of the bill they sign (Çelebi \& Tatık, 2012; Erdoğan, 2013; Karakütük \& Özdemir, 2011).

- participants are having difficulty in establishing strong ties with both the host and the protocol university as well as the training staff (Erdoğan, 2013; Kahraman, 2007; Karakütük \& Özdemir, 2011)

\section{The Purpose of the Research}

Studies addressing the conditions and experiences of professionals working in higher education is insufficient (Rhoades, 2007), and factors shaping the professional identity of academics has not been researched in depth (Clarke, Hyde, \& Drennan, 2013). As mentioned in the literature, graduate education as the early socialization into academic profession plays a significant role in developing the key concepts of academic identity; therefore, an investigation into the recruitment of graduate students as future academics deserves attention. In addition, findings of the existing studies reveal a strong need for a deeper evaluation of Academic Training Program (ÖYP) since some serious problems seem to be experienced by the participants that might influence their academic identity. There is also a need to investigate the program from the perspective of the faculty that offers training since our literature review did not yield any studies investigating faculty views on the effectiveness of the program in developing a strong professional identity. Bearing the gap in the literature, the present study aims to investigate Academic Training Program (ÖYP) in the light of academics' definition of the characteristics of academic profession, with a focus on professional socialisation and identity development.

\section{Research Methodology}

This study employs a qualitative collective instrumental case study approach. Qualitative studies help the researcher to build a complex, holistic picture of a social or human problem in its natural settings (Creswell, 1998). A collective instrumental case study is a method to explore a particular phenomenon or issue by studying more than one case to be able to understand the issue or phenomenon in a broader sense (Stake, 1995). The use of a collective instrumental case study approach is useful to explore academics' definition of the characteristics of academic profession and the compatibility of Academic Training Program (ÖYP) with these defined characteristics. Thus, it would be possible to highlight issues that require deeper exploration and to gather more compelling evidence that could expand the external ability to generalize the findings (Stake, 2006). 
Participants were twenty-four academics from typical Turkish state universities, and they were selected using the maximum variation sampling method. This purposeful sampling method allows for data variation through selection of participants with the most divergent forms of the experience and helps to reach informationrich cases which can provide rich data about issues of central importance to the purpose of the evaluation, rendering the study more representative (Patton, 1990). With this purpose, participants with different disciplinary backgrounds, titles, genders and ages were selected to display maximum variation. The demographics of the participants are presented in Table 1.

Data for the present study were gathered through approximately one-hour long, semi-structured, uninterrupted interviews. Questions were generated to inquire participants' professional life experiences regarding the selection, recruitment and training of candidate academics. As declared on the consent sheet, all personal identifiers were removed to preserve anonymity and each participant was given a unique code (Table 1). Data were analyzed with the method of constant comparison suggested by Glaser and Strauss (1967) and recurring themes were obtained. Responses of each participant were checked for conflicting or ambiguous views, and only consistently repeated themes that were without contradiction were maintained. In addition, data were analyzed by two researchers independently to ensure convergence in interpretation as Miles and Huberman (1994) suggest. Finally, the findings were discussed with two uninvolved peers to check reliability.

Table 1. Demographics of the Participants

\begin{tabular}{|c|c|c|c|c|c|}
\hline Discipline & Code & Gender & Age & Title & Sub-disciplines \\
\hline \multirow{8}{*}{ Soft Sciences } & $\overline{\mathrm{FS}-1}$ & $\mathrm{~F}$ & $\overrightarrow{52}$ & $\overline{\text { Professor }}$ & Turkish Literature \\
\hline & FS-2 & $\mathrm{F}$ & 43 & Assoc. Prof. & Philosophy \\
\hline & FS-3 & $\mathrm{F}$ & 48 & Assist. Prof. & English Linguistics \\
\hline & FS-4 & $\mathrm{F}$ & 35 & Assist. Prof. & Medieval History \\
\hline & MS-1 & M & 39 & Assist. Prof. & Sociology \\
\hline & MS-2 & M & 36 & Assist. Prof. & Turkish Literature \\
\hline & MS-3 & M & 40 & Assist. Prof. & Medieval History \\
\hline & MS-4 & M & 39 & Assist. Prof. & Turkish History \\
\hline \multirow{8}{*}{ Hard Sciences } & FH-1 & $\mathrm{F}$ & 52 & Assist. Prof. & Organic Chemistry \\
\hline & FH-2 & $\mathrm{F}$ & 45 & Assoc. Prof. & Inorganic Chemistry \\
\hline & FH-3 & $\mathrm{F}$ & 46 & Professor & Biochemistry \\
\hline & FH-4 & $\mathrm{F}$ & 46 & Assist. Prof. & Molecular Biology \\
\hline & MH-1 & M & 43 & Assoc. Prof. & Inorganic Chemistry \\
\hline & MH-2 & M & 42 & Assoc. Prof. & Inorganic Chemistry \\
\hline & MH-3 & M & 48 & Assist. Prof. & Pharmaceutical Chemistry \\
\hline & MH-4 & M & 38 & Assoc. Prof. & Biochemistry \\
\hline \multirow{8}{*}{$\begin{array}{l}\text { Applied } \\
\text { Sciences }\end{array}$} & FA-1 & $\mathrm{F}$ & 45 & Assist. Prof. & Thermodynamics \\
\hline & FA-2 & $\mathrm{F}$ & 44 & Assist. Prof. & Chemical Technologies \\
\hline & FA-3 & $\mathrm{F}$ & 53 & Professor & Thermodynamics \\
\hline & FA-4 & $\mathrm{F}$ & 36 & Assist. Prof. & Thermodynamics \\
\hline & MA-1 & M & 40 & Assist. Prof. & Bio-engineering \\
\hline & MA-2 & M & 50 & Assist. Prof. & Chemical Engineering \\
\hline & MA-3 & M & 48 & Professor & Construction-Production \\
\hline & MA-4 & M & 39 & Assist. Prof. & Electrics - Electronics \\
\hline
\end{tabular}

\section{Results}

Participants of the study shared their opinions regarding Academic Training Program (ÖYP) in comparison with the characteristics of academic profession and central elements of academic identity. Analysis of the data revealed that participants defined three central elements of academic profession and indicated that the program gives harm to these three elements. A summary of the findings can be seen in Table 2 . 


\begin{tabular}{|c|c|}
\hline Academic profession; & Academic Training Program \\
\hline - requires mentor-protégé relationship & - preclude a healthy mentor-protégé relationship \\
\hline $\begin{array}{l}\text { - requires some personal characteristics (e.g. } \\
\text { curiosity, a questioning mind, individual } \\
\text { autonomy, self-confidence, self-sacrificing, } \\
\text { self-regulation, love of knowledge and } \\
\text { learning) }\end{array}$ & $\begin{array}{l}\text { - lacks the presence of required personal characteristics; } \\
\text { admission criteria is based on paper-pencil exam (ALES) }\end{array}$ \\
\hline $\begin{array}{l}\text { - is not only a means of earning money, but a } \\
\text { way of serving humanity, so it should be } \\
\text { considered more than a job }\end{array}$ & $\begin{array}{l}\text { - attracts candidates due to job guarantee; there is not a clear } \\
\text { guidance for job selection }\end{array}$ \\
\hline
\end{tabular}

\subsection{Requirement of a Mentor-Protégé Relationship}

Participants state that one of the significant roles of academics is training future academics. They all highlight that a successful academic career builds upon a healthy mentor-protégé relationship during graduate education. They believe this mentor-protégé relationship is a prerequisite for the continuity of disciplinary thought (FS-1, FS-2) and the training of qualified academics (MS-1, MS2, FH-3, MA-4).

Studying with high-quality academics during graduate education is really important. This is a must. Only then the student can become a qualified academic. Working together like a mentorprotégé, this is what matters (MS-2).

Mentor-protégé relationship and relay race; these two metaphors define the requirements of a qualified academic training. Supervisor is really important; if the student is working with a good supervisor who can mentally feed him/her, who can become a role model, then the student can become a qualified academic in the future. This is what we must never forget (FH-3)

Participants underline the fact that the most significant negative effect of Academic Training Program (ÖYP) is to this mentor-protégé relationship. They believe the admission and recruitment procedures of the program prevent developing a healthy relationship between students and supervisors. Students have difficulty in becoming an established member of both the host and protocol university, and in building a sincere relationship with their supervisors. Similarly, supervisors and the other faculty have problems seizing upon what these students have brought. Many of the participants (MS-1, MH-3, MA-2, FH-3, FA-3, MA-3) state that these obstacles create serious problems diminishing the quality of future academics.

Neither the students could embrace the university and us nor could we embrace them. We do not have a say in selecting the candidates. That is the biggest mistake, I believe. If we are qualified as academics, we must be part of the admission process (FH-3).

ÖYP has ended this mentor-protégé relationship, so training future academics has become much more problematic. This also damages the continuity of disciplinary thought (FS-4).

The problem also seems to continue after graduates return to their protocol universities. Since these universities are newly-established, they lack many facilities as well as sufficient number of qualified faculty. However, when graduates return to these universities, they not only lose the advantages and supports provided by their host university but also are expected to develop their new institution despite still being a novice academic. One of the participants expresses the situation well with her following remarks:

Lots of universities have been established. Mentor-protégé relationship between candidate and existing academics has been abolished with this new training programs, I mean ÖYP. What happened then? 'Protégés' have been left alone in their universities, mostly overwhelmed by the expectations from them. This also caused problems of ethics and integrity. As a result, both the quality of education and the quality of academics has decreased, unfortunately (FH-3).

\subsection{Requirement of Particular Personal Qualities}

Participants point out some qualities that are necessary to become a successful academic, and they state that current system of selecting candidate academics in ÖYP is inefficient for determining the existence of these qualities in the candidates. Participants highlight the importance of such personal qualities as curiosity, questioning mind, love of humanity, respectfulness, integrity, individual autonomy, self-confidence, selfregulation, love of knowledge and learning.

I believe we must select candidates well. Being hard-working is okay but not enough. Ethics is more important, for example; personality, character, these are all important when selecting and training future academics. Existence of all these should be evaluated by a board of academics 
(FS-3).

Especially with ÖYP, personal characteristics have begun to be neglected. But this is not good

because character analysis is necessary to select the best candidates (FM-4).

Participants also point out that selection of candidates based on a single paper-pencil exam prevents the evaluation of candidates' teaching and research skills as well as personal qualities. In ÖYP program, selection is mainly based on ALES (Academic Personnel and Post-graduate Training Examination) and the exam only comprises of mathematical and some basic reasoning skills. Participants believe that academic profession require higher order thinking skills as well as a solid disciplinary knowledge, claiming that ALES is far away from evaluating these skills and knowledge.

Those who are successful in ALES become the art of academe, but many do not know how to talk to audiences, may lack even disciplinary knowledge base. Our job is half research, half teaching. A good academic must have good teaching skills as well. That's why academics must take part in the evaluation of candidates (FH-3).

It is not right to evaluate people just based on having 2-3 more correct answers than others. This does not give any clues whether they are better candidates for becoming academics. With this selection system, unfortunately we sometimes block the way for candidates with higher potentials (MA-3).

\subsection{Requirement of Conscious Selection}

Participants share the idea that academic profession is not only a job that people do to earn money but it requires a strong love of knowledge and humanity as well as being ready to self-sacrifice. Many of the participants underline the importance of a conscious selection of the profession as well as the necessity of internalizing it as a lifestyle rather than just a job since academic profession requires hard work and strong commitment. They agree that earning neither money nor titles should be a priority for the academic. However, participants state that ÖYP program does not include a proper guidance system nor it includes mechanisms that could prevent happenstance entry into academe. In contrast, participants claim that the program increases the chances of becoming an academic happenstance since many applicants take advantage of the job guarantee that the program offers.

Those who have never dreamed of becoming an academic find themselves in the academe, usually not knowing what to do or even not willing to do anything at worst. There are lots of examples. Can we expect them to be successful or solid members of the academe? I do not think so (MH-4).

\section{Discussion and Conclusion}

Academic identity is not only related to the question of who I am but also who I want to become in the future (Beijaard et al., 2004), and the answers to these questions are mainly shaped by the professional socialisation that start during graduate education. Throughout graduate education, candidate academics begin to learn about the attitudes, actions and values of those performing academic profession, all of which shape their academic identity (Clarke et al., 2013; Kogan, 2000; Tierney \& Rhoads, 1993; Weidman et al., 2001). Academic identity which encompass academics' attitudes, behaviours, judgments and values regarding their profession is significant since it determines the way they perform their professional roles (Arasa \& Calvert, 2013; Austin, 1990). The findings of the present study reveal that Academic Training Program (ÖYP), which mainly regulates the selection and training of future academics, could lead to some negative outcomes that might prevent candidate academics from building a strong academic identity.

Weidman et al. (2001) determine three important aspects of graduate students' socialisation as knowledge acquisition, investment (transmission of accepted values of the profession for successful professional practice) and involvement (taking pride in becoming a member of the profession and developing an interest in a profession's problems). In terms of the investment and involvement stages, they highlight the importance of normative dimension of graduate education which includes the development of values, ethics and personal commitments to professional society. According to them, "if entering graduate students are to succeed in their new environments, they must learn not only to cope with the academic demands but also to recognize values, attitudes, and subtle nuances reflected by faculty and peers" ( p. 16). For a successful progression through graduate education, both personal and professional relationship between the mentor and the graduate student is necessary since the graduate student can only develop a healthy academic identity based on the attention, help, advice, information and encouragement that the supervisor provides (Weidman et al., 2001). In the context of academic profession, mentors and the other faculty are both trainers and professional role models, which makes the relationship between students and faculty more crucial. The findings of the present study also highlight the importance of this relationship and points out to some pitfalls of ÖYP from this aspect. According to our results, academics have difficulty building a reciprocal and friendly relationship with students who are centrally appointed to graduate programs since both parties have difficulty in coming to terms with each others' 
expectations. As a result, socialisation process is likely to end with only knowledge acquisition, leaving out the investment and involvement stages.

Academic identity encompasses the individual with his/her own history and cultural framework as well as the characteristics of the communities surrounding him/her (Henkel, 2000; Kogan, 2000). Therefore, both individual qualities and the characteristics of the institution play an important role in the development of individuals as academics. The findings of the present study reveal that ÖYP lacks the evaluation of person-job fit in terms of required personal characteristics. Previous research also indicates that some candidates are attracted by the job guarantee offered by the program rather than their interest in the profession (Erdoğan, 2013; Memiş \& Sağır, 2013). As a result, mentors are urged to train those incompatible candidates into an academic while candidates are urged to become an academic even if they discovered that it is not the right job for them. Because recruits sign a bill before entering into the program, they have to continue their academic career even if they do not want to. Studies carried out with the recruits show that they feel the pressure of the bill all through the process and some continue to be an academic just because they cannot pay this bill (Erdoğan, 2013; Kahraman, 2007; Karakütük \& Özdemir, 2011).

Moreover, as the findings suggest, the program disregards the influence of institutional impact on the development of academic identity since candidates are urged to work in an environment which often lacks the support that a novice academic needs. After graduation from a developed university, these novice academics are sent to a newly established institution with its own problems and insufficiencies. As a result, some tend to have difficulty sticking to the values and ideals they acquired during graduate education. As a result, ideals like earning money or titles and enjoying the prestige of the profession could become priority, weakening their commitment to professional values and job roles. Previous research also shows that recruits of the program have difficulty adapting to their protocol university and building a strong organisational commitment (Çelebi \& Tatık, 2012; Erdoğan, 2013; Kahraman, 2007). Our findings might also explain the reason behind these problems of adaptation and commitment.

A successful progression into academic profession requires a more interactive and dynamic socialisation process which emphasises personal, professional and academic connectedness that could also serve as a networking strategy during and after graduate education (Twale \& Kochan, 2014). In its current state, ÖYP has a structure which offers a "linear model of socialisation process" (Weidman et al., 2001, p. 38). With this program, students are graduated after completing a specific program of study with a limited chance of professional socialization and sent to work on their own. The program needs to be developed in a way that existing faculty actively takes part in the process of selecting and training candidates based on faculty expectations, university standards and professional outcomes. Thus, it could be possible to make sure whether the candidates selected are ready to assume professional roles and the graduates are prepared well enough to perform these roles adequately.

\section{References}

Arasa, J. N., \& Calvert, M. (2013). Negotiating professional identities in higher education in Kenya: dilemmas and priorities of faculty. Research in Post-Compulsory Education, 18(4), 402-414. doi: 10.1080/13596748.2013.847232

Austin, A. E. (1990). Faculty Cultures, Faculty Values. New Directions for Institutional Research, 68, 61-74. doi: 10.1002/ir.37019906807

Beijaard, D., Meijer, P. C., \& Verloop, N. (2004). Reconsidering research on teachers' professional identity. Teaching and Teacher Education, 20(2), 107-128. doi: DOI 10.1016/j.tate.2003.07.001

Bruss, K. V., \& Kopala, M. (1993). Graduate school training in psychology: Its impact upon the development of professional identity. Psychotherapy: Theory, Research, Practice, Training, 30(4), 685. doi: 10.1037/0033-3204.30.4.685

Clarke, M., Hyde, A., \& Drennan, J. (2013). Professional identity in higher education The academic profession in Europe: New tasks and new challenges (pp. 7-21): Springer.

Creswell, J. W. (1998). Qualitative inquiry and research design: Choosing among five designs: Thousand Oaks, CA: Sage.

Çelebi, N., \& Tatık, R. Ş. (2012). Öğretim Üyesi Yetiştirme Programındaki (ÖYP) Araştırma Görevlilerinin ÖYP'yi Değerlendirmeleri. Journal of Higher Education/Yüksekögretim Dergisi, 2(3).

Erdoğan, M. (2013). Facilities, Challenges and Contributions of Faculty Development Program from the Perspective of Students and Graduates: The Case of METU. Master's, Middle East Technical University, Ankara.

Glaser, B., \& Strauss, A. (1967). The Discovery of Grounded Theory: Strategies for Qualitative Research. London: Wiedenfeld and Nicholson.

Henkel, M. (2000). Academic identities and policy change in higher education. London: Kingsley.

Ibarra, H. (1999). Provisional selves: Experimenting with image and identity in professional adaptation. 
Administrative Science Quarterly, 44(4), 764-791. doi: 10.2307/2667055

Josselson, R. (1987). Finding herself: Pathways to identity development in women. San Francisco, CA, US: Jossey-Bass.

Kahraman, L. (2007). Türkiye'de Öğretim Üyesi Yetiştirme Politikası Bağlamında" 35. Madde" Uygulaması. Mülkiye Dergisi, 31(256), 187-192.

Karakütük, K., \& Özdemir, Y. (2011). Bilim insanı yetiştirme projesi (BİYEP) ve öğretim üyesi yetiştirme programı'nın (ÖYP) değerlendirilmesi. Eğitim ve Bilim, 36(161).

Kogan, M. (2000). Higher education communities and academic identity. Higher Education and Its Communities, 29-37. doi: 10.1111/1468-2273.00156

Memiş, P., \& Sağır, A. (2013). ÖYP as a new form of employment in higher education Yükseköğretimde yeni (lenmiş) istihdam örneği olarak ÖYP. Journal of Human Sciences, 10(1), 74-100.

Miles, M. B., \& Huberman, A. M. (1994). Qualitative data analysis: An expanded sourcebook. Thousand Oaks, CA, US: Sage Publishing, Inc.

Patton, M. Q. (1990). Qualitative evaluation and research methods. Thousand Oaks, CA, US: SAGE Publications, inc.

Reybold, L. E. (2003). Pathways to the professorate: The development of faculty identity in education. Innovative Higher Education, 27(4), 235-252. doi: 10.1023/A:1024024430041

Rhoades, G. (2007). The Study of Academic Profession. In P. J. Gumport (Ed.), Sociology of Higher Education: contributions and their contexts (pp. 113-146). Baltimore: The Johns Hopkins University Press.

Stake, R. E. (1995). The art of case study research. Thousand Oaks, California: Sage Publishing.

Stake, R. E. (2006). Multiple case study analysis. New York: Guilford Press.

Tierney, W. G., \& Rhoads, R. A. (1993). Enhancing Promotion, Tenure and Beyond: Faculty Socialization as a Cultural Process. ASHE-ERIC Higher Education Report No. 6: ERIC.

Twale, D. J., \& Kochan, F. K. (2014). Assessment of an alternative cohort model for part-time students in an educational leadership program. Journal of School Leadership, 10(2), 188-196.

Weidman, J. C., Twale, D. J., \& Stein, E. L. (2001). Socialization of Graduate and Professional Students in Higher Education: A Perilous Passage? ASHE-ERIC Higher Education Report, Volume 28, Number 3. Jossey-Bass Higher and Adult Education Series: ERIC. 